The most frequent vascular territories afected were abdominal Ao (7), descending thoracic Ao (5) and iliac arteries (5). The most common type of arterial lesion was stenosis (8) followed by dilation and aneurysm. 6 patients were treated with corticotherapy as an induction treatment, 5 required chronic immunosuppression and 6 patients required surgery. When reviewing the criteria we observed that all patients met the ACR criteria and 7 patients met the modified criteria by Sharma. However, the agreement with Ishikawa's diagnostic criteria was poor since 7 patients did not meet them. The different criteria are shown in Table 2.

\begin{tabular}{|c|c|c|c|c|c|}
\hline Ishikawa, n (\%) & & $\begin{array}{c}1990 \text { ACR, } \\
\text { n (\%) }\end{array}$ & & $\begin{array}{c}\text { Modified } \\
\text { Ishikawa, } \mathrm{n}(\%)\end{array}$ & \\
\hline Age $\leq 40$ yrs & $7(77,8)$ & Age $<40$ yrs & $\begin{array}{c}7 \\
(77,8)\end{array}$ & $\begin{array}{l}\text { Left subclavian } \\
\text { lesion }\end{array}$ & $4(44,4)$ \\
\hline $\begin{array}{l}\text { Left subclavian } \\
\text { lesion }\end{array}$ & $4(44,4)$ & $\begin{array}{c}\text { Claudication } \\
\text { of } \\
\text { extremities }\end{array}$ & $\begin{array}{c}5 \\
(55,6)\end{array}$ & $\begin{array}{l}\text { Right } \\
\text { subclavian } \\
\text { lesión }\end{array}$ & $3(33,3)$ \\
\hline $\begin{array}{l}\text { Right } \\
\text { subclavian } \\
\text { lesion }\end{array}$ & $3(33,3)$ & $\begin{array}{l}\text { Decreased } \\
\text { brachial } \\
\text { artery pulse }\end{array}$ & $\begin{array}{c}4 \\
(44,4)\end{array}$ & $\begin{array}{l}\text { Clinic at least } 1 \\
\text { month duration, }\end{array}$ & $9(100)$ \\
\hline$V S G \geq 20 \mathrm{~mm} / \mathrm{h}$ & $4(66,6)$ & $\begin{array}{c}\mathrm{BP} \\
\text { difference } \\
>10 \mathrm{mmHg}\end{array}$ & $\begin{array}{c}5 \\
(55,6)\end{array}$ & VSG $>20 \mathrm{~mm} / \mathrm{h}$ & $4(66,6)$ \\
\hline $\begin{array}{l}\text { Carotid artery } \\
\text { tenderness }\end{array}$ & 0 & $\begin{array}{l}\text { Bruit over } \\
\text { subclavian } \\
\text { arteries or } \\
\text { Ao }\end{array}$ & $\begin{array}{c}4 \\
(44,4)\end{array}$ & $\begin{array}{c}\text { Carotid artery } \\
\text { tenderness }\end{array}$ & 0 \\
\hline HTA & $4(44,4)$ & $\begin{array}{l}\text { Arteriogram } \\
\text { abnormality }\end{array}$ & $\begin{array}{c}9 \\
(100)\end{array}$ & HTA & $4(44,4)$ \\
\hline $\begin{array}{l}\text { Aortic } \\
\text { regurgitation }\end{array}$ & $3(37,5)$ & & & $\begin{array}{c}\text { Aortic } \\
\text { regurgitation }\end{array}$ & $3(37,5)$ \\
\hline $\begin{array}{l}\text { Pulmonary } \\
\text { artery lesion }\end{array}$ & 0 & & & $\begin{array}{l}\text { Pulmonary } \\
\text { artery lesion }\end{array}$ & 0 \\
\hline $\begin{array}{l}\text { Common } \\
\text { carotid lesion }\end{array}$ & $2(22,2)$ & & & $\begin{array}{l}\text { Common } \\
\text { carotid lesion }\end{array}$ & $2(22,2)$ \\
\hline $\begin{array}{l}\text { Distal } \\
\text { brachiocephalic } \\
\text { trunk lesion }\end{array}$ & $2(22,2)$ & & & $\begin{array}{l}\text { Distal } \\
\text { brachiocephalic } \\
\text { trunk lesion }\end{array}$ & $2(22,2)$ \\
\hline $\begin{array}{l}\text { Descending } \\
\text { thoracic Ao } \\
\text { lesion }\end{array}$ & $5(55,6)$ & & & $\begin{array}{l}\text { Descending } \\
\text { thoracic Ao } \\
\text { lesion }\end{array}$ & $5(55,6)$ \\
\hline \multirow[t]{2}{*}{$\begin{array}{l}\text { Abdominal Ao } \\
\text { lesion }\end{array}$} & $7(77,8)$ & & & $\begin{array}{l}\text { Abdominal } \\
\text { aorta lesion }\end{array}$ & $7(77,8)$ \\
\hline & & & & $\begin{array}{c}\text { Coronary artery } \\
\text { lesion }\end{array}$ & $2(33,3)$ \\
\hline
\end{tabular}

Conclusion:

- The most frequently affected vascular territory was the abdominal Ao, and the most common type of injury was stenosis.

- The most common clinical presentation was asymmetry of blood pressure between extremities and peripheral pulses, HTA and limb claudication.

- All patients met the ACR 1990 classification criteria and the great majority met the criteria modified by Sharma. The concordance with Ishikawa's criteria was poor so they should be used cautiously.

Disclosure of Interests: Andrea García-Guillén: None declared, Patricia Moya: None declared, Antonio José Barros-Membrilla: None declared, Jaime Félix Dilme: None declared, José Montiel: None declared, José Alberto Hidalgo: None declared, Albert Flotats: None declared, Alejandro Fernandez: None declared, Josep Maria Llobet: None declared, Berta Magallares: None declared, Ana Laiz Consultant for: Lilly, Novartis, AbbVvie, MSD, UCB and Janssen, Speakers bureau: Lilly, Novartis, Abvvie, MSD, UCB and Janssen, Ivan Castellví Consultant for: I received fees less than 5000USD as a consultant for Kern and Actelion, Paid instructor for: I received fees less than 2000USD as a instructor for Boehringer -Ingelheim, Novartis and Gebro, Speakers bureau: ND, Hector Corominas: None declared DOI: 10.1136/annrheumdis-2019-eular.4036

\section{AB0587 CLINICAL MANIFESTATIONS OF BEHCET'S DISEASE DEPENDING ON GENDER: A REVIEW OF 425 CASES IN RUSSIA}

Zemfira Alekberova, Tatiana Lisytsyna, Regina Goloeva. V.A. Nasonova Research Institute of Rheumatology, Moscow, Russian Federation

Background: The gender-related differences in clinical course of Behcet's disease (BD) are well-established, and more severe course is usually observed among young males.

Objectives: To analyze the effect of gender on the severity and clinical features of BD.

Methods: The study included 425 patients (male - 285, female - 140) with BD (according to ISGBD 1990 and ICBD criteria 2014) [1, 2]. The male-to-female ratio was $2: 1$, the mean age was $33,2 \pm 10,2$ yrs, the median of disease duration - $134,3[60,0 ; 192,0]$ months.

Results:

General characteristics of BD-patients depending on gender

\begin{tabular}{|c|c|c|c|}
\hline General characteristics & Male, $n=285$ & Female, $n=140$ & $\mathrm{p}$ \\
\hline Age of pts, yrs $(\mathrm{M} \pm S D)$ & $32,5 \pm 9,72$ & $34,9 \pm 10,8$ & ns \\
\hline $\begin{array}{l}\text { Disease duration (Me }[25 \% \text {; } \\
75 \%] \text { ) }\end{array}$ & $96,0[60,0 ; 192,0]$ & $\begin{array}{l}108,0[60,0 \\
\quad 216,0]\end{array}$ & ns \\
\hline Age of disease onset, yrs $(M \pm S D)$ & $21,2 \pm 9,71$ & $22,8 \pm 11,5$ & ns \\
\hline Activity (BDCAF), (M $\pm S D)$ & $3,71 \pm 2,02$ & $2,64 \pm 1,45$ & 0,0002 \\
\hline HLA-B5(51) +, n (\%) & $\begin{array}{l}129 \text { from } 193 \\
(67)\end{array}$ & $\begin{array}{l}52 \text { from } 101 \\
(51,5)\end{array}$ & 0.007 \\
\hline
\end{tabular}

BD severity depending on gender

\begin{tabular}{lccc}
\hline $\begin{array}{l}\text { BD severity, } \mathrm{n} \\
(\%)\end{array}$ & Male, & Female, & $\mathrm{p}$ \\
$\mathrm{n}=285$ & $\mathrm{n}=140$ & \\
\hline Mild & $48(17)$ & $57(41)$ & $<0,001$ \\
Moderate & $29(10)$ & $14(10)$ & $\mathrm{ns}$ \\
Severe & $208(73)$ & $69(49)$ & $<0,001$ \\
\hline
\end{tabular}

We observed the following gender-related differences in clinical manifestations of BD: males significantly more often had uveitis ( $74 \%$ vs $57 \%, p=0,0003)$, optic neuritis $(11 \%$ vs $0 \%, p=0,0004)$, blindness ( $9 \%$ vs $2,5 \%, p=0,04)$; cutaneous lesions ( $89 \%$ vs $71 \%, p<0,001)$, such as pseudo-folliculitis ( $53 \%$ vs $21 \%, p=0,001)$, positive pathergy test $(39,6 \%$ vs of $24,3 \%, p=0,001)$; severe vascular involvement (vena cava and iliac vein thrombosis, deep vein thrombosis, arterial thrombosis and arterial aneurism) ( $27 \%$ vs $11 \%, p=0,001)$, cerebral sinus thrombosis ( $9 \%$ vs $3 \%, p=0,015)$ and genital ulcers $(77,9 \%$ vs $67,1 \%, p=0,012)$ compared with females. Male BD-pts more often had HLA-B5(51)-positivity (67\% vs $51,5 \%$, $p=0,007$ ), higher BD activity (BDCAF $-3,71 \pm 2,02$ vs $2,64 \pm 1,45, p<0,001$ ) and BD severity (severe $B D$-course $-73 \%$ vs $39 \%, p<0,001$ ). Mortality rate in this $B D$ cohort was $1,2 \%$, and all 5 cases were young males aged under 30 years.

Conclusion: An association of severe clinical manifestations (ophthalmological and vascular, such as large vessels and cerebral sinus thrombo ses), higher disease activity \& severity, as well

Disclosure of Interests: None declared

DOI: 10.1136/annrheumdis-2019-eular.6663

\section{AB0588 GASTROINTESTINAL INVOLVEMENT OF BEHCET'S DISEASE IN RUSSIA}

Regina Goloeva, Zemfira Alekberova. V.A. Nasonova Research Institute of Rheumatology, Moscow, Russian Federation

Background: Behcet's disease (BD) is a multisystem vasculitis with unknown etiology and a unique geographical distribution. Intestinal manifestations of $\mathrm{BD}$ (IBD) are of particular importance as they are associated with significant morbidity and mortality. Although ileocecal involvement is most commonly described, BD may involve any segment of the intestinal tract as well as the various organs within the gastrointestinal system.

Objectives: To analyze the severity and clinical features IBD in Russia

Methods: The study included 250 patients (male - 177, female - 73) with BD (according to ISGBD 1990 and ICBD criteria 2014). The male to-female ratio was $2,4: 1$, the mean age was $31,5 \pm 9,3 \mathrm{yrs}$, the age of disease onset - $21.8 \pm 9.62 \mathrm{yrs}$, the median of disease duration - 10.25 \pm 8.32 yrs. All those with gastrointestinal symptoms were subject to a gastroscopy and/or colonoscopy through which Crohn's disease and ulcerative colitis were excluded by the proctologists.

Results: Patients with gastrointestinal symptoms were 63 of $250-25.2 \%$ pts, (male - 40, female - 23). Symptoms of IBD include the abdomina pain in $62 \%$ pts, distension $-55 \%$, diarrhea $-14 \%$, nausea $-13 \%$, blood in the bowel movement $-4,7 \%$. The examination revealed: esophagea ulcers $(1.6 \%$, four cases), gastric ulcers $(3.2 \%$, eight cases), and duodenal ulcers (1.2\%, three cases) were found using endoscopy. Also, $6.8 \%$ (17 patients) had gastro duodenal ulcers and 14.3\% (nine patients) combined gastrointestinal involvement including esophageal and had gastro duodenal ulcers. Colonic ulcers were detected in $9.2 \%$ (23 cases) by colonoscopy, two patients had multisegmental diffuse ulceration, three patients had in the sigmoid colon and of everyone else in the ileum. Ccolitis without ulcers found in $5,6 \%$ (14 cases). Two patients had a clinic of appendicitis, the operation found that the appendix is not inflamed. Two patients were $0.8 \%$ (were on treatment) urgently operated due to perforation of ulcers of the ileum, the woman held suturing of perforated ulcer, and a man - hemicolectomy. The last patient has a relaparotomy after 1 month and removal of the entire colon.

Conclusion: The IBD in Russia is affected in $1 / 4$ of patients, but heavy refractory forms not often. 
Disclosure of Interests: None declared

DOI: 10.1136/annrheumdis-2019-eular.6778

\section{AB0589 ANCA ASSOCIATED VASCULITIS: OUR EXPERIENCE FROM A TERITIARY CARE CENTER OVER 10 YEARS}

Anjani Gummadi ${ }^{1}$, Ankita Singh ${ }^{1}$, Sandesh Guleria ${ }^{2}$, Pandiarajan Vignesh ${ }^{2}$, Anju Gupta ${ }^{1}$, Deepti Suri ${ }^{2}$, Ankur Jindal ${ }^{3}$, Biman Saikia ${ }^{4}$, Amit Rawat ${ }^{3}$, Surjit Singh ${ }^{2} .{ }^{1}$ Post Graduate Institute of Medical Education and Research, Chandigarh, Pediatrics, Advanced Pediatric centre, Chandigarh, India; ${ }^{1}$ Post Graduate Institute of Medical Education and Research, Chandigarh, Pediatrics, Advanced Pediatric centre, Chandigarh, India; ${ }^{3}$ Post Graduate Institute of Medical Education and Research, Chandigarh, Chandigarh, India; ${ }^{4}$ Post Graduate Institute of Medical Education and Research, Chandigarh, Department of Immunopathology, Chandigarh, India

Background: The anti-neutrophil cytoplasmic antibody (ANCA)- associated vasculitides (AAV) are a group of disorders characterized by necrotizing inflammation of the small to medium vessels in association with autoantibodies. Childhood ANCA vasculitides are rare but can cause organ or even life-threatening systemic vasculitis. Children most frequently present with rapidly evolving, severe disease.

Objectives: To describe the clinical spectrum of ANCA associated vasculitis, the treatment given and follow up

Methods: A single-centre retrospective analysis of ANCA associated vasculitis over a period of 10 years from 2008 to 2018

Results: Six children (2 boys; 4 girls) were diagnosed to have AAV during this period. Median age at diagnosis was 11.25 years (range 8-18 years). Median delay in diagnosis was 1.5 months (range 1-8 months). Presenting clinical features included lung disease- 4 children; arthritis- 3 (knee, right ankle-left $3^{\text {rd }} \mathrm{MCP}$, left elbow-knee) hemoptysis- 2 children; ear discharge- 1; redness of eye-1; oliguria, gross hematuria-2; anasarca2; 2 children had concomitant neurological symptoms (left foot drop, quadriparesis with seizures). All children had fever at presentation. Laboratory investigations showed elevated erthrocyte sedimentation rate(ESR) and C-reactive protein(CRP). ANCA testing was positive in 6 children (3 c-ANCA, +PR3, 3 p-ANCA, +MPO). Deranged renal function tests, proteinuria, microscopic hematuria) were seen in 4 out of 6 children. Renal biopsy showed pauci immune glomerulonephritis in 4 cases who presented with nephritis. All patients were treated with 5 pulses of intravenous methylprednisolone $(30 \mathrm{mg} / \mathrm{kg} /$ day $)$ with tapering doses of oral steroids. Intravenous cyclophosphamide pulses was given in 5 children while 1 received additional plasmapheresis (PLEX)- 8 cycles. Mintainence therapy included azathioprine(given in 5 children), low-dose prednisolone. Thrombocytopenia was noted in 1 child while on azathioprine; this was subsequently substituted with mycophenolate mofetil. Two children have been lost to follow-up. Median duration of follow-up is 35.5 months (range 8-124 months). All 4 children have attained remission with good compliance and there are no relapses.

Conclusion: While an evidence base treatment of AAV in children is limited, our data suggests that prolonged remission can be achieved with aggressive immnosupressive therapy, however prognosis of childhood AAV remains guarded.

Table: Characteristics of children enrolled in study

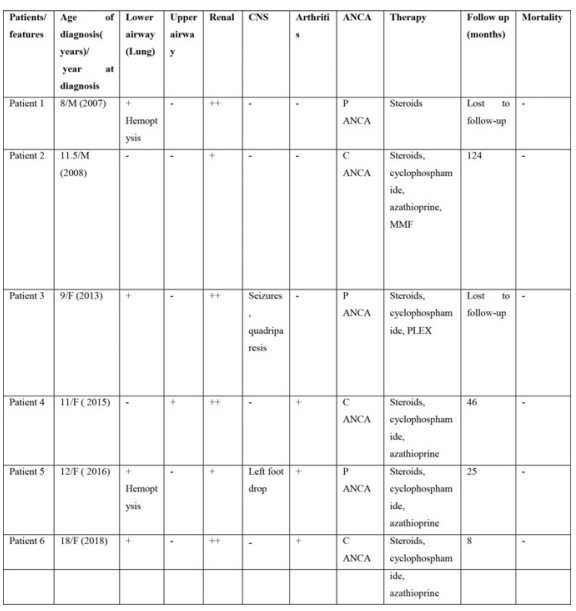

Disclosure of Interests: None declared DOI: 10.1136/annrheumdis-2019-eular.8244

\section{$\mathrm{AB} 0590$ \\ A SINGLE CENTER RETROSPECTIVE ANALYSIS OF EFFICACY AND SAFETY BETWEEN LOW-DOSE VERSUS HIGH-DOSE RITUXIMAB AS REMISSION INDUCTION THERAPY IN JAPANESE PATIENTS WITH ANCA-ASSOCIATED VASCULITIS}

Kei Hirose, Manami Hirata, Yuriko Yamamura, Akiko Ueno, Masahiro Yamamura. Okayama Saiseikai General Hospital, Center for Rheumatology, Okayama city, Japan

Background: Administration of four once-weekly doses of $375 \mathrm{mg} / \mathrm{m}^{2}$ rituximab (RTX) has been indicated for ANCA-associated vasculitis (AAV) as remission induction therapy. However, randomized controlled trial for Japanese AAV patients have never been conducted, although Japanese AAV patients are characterized by the predominance of elderly patients with microscopic polyangiitis (MPA)

Objectives: To compare the efficacy and safety between low-dose versus high-dose RTX therapy as remission induction therapy in Japanese patients with AAV.

Methods: A single center retrospective analysis of 27 consecutive AAV patients with RTX therapy was performed. Clinical and laboratory variables at diagnosis, rates of complete remission (CR), defined as Birming ham Vasculitis Activity Score (BVAS) $=0$ and prednisone $<7.5 \mathrm{mg} /$ day, adverse effects, and vasculitis relapses following RTX use.

Results: Twenty-five MPA patients and 2 GPA patients $(14$ males and 13 females) were included in the present study. Twenty-six patients were positive for MPO-ANCA. Their median age was 77 years (range: 40-85 years). Treatments were determined according to the discretion of the attending physician. As remission induction therapy, 18 patients were treated with once or twice (1/2) RTX infusions $\left(375 \mathrm{mg} / \mathrm{m}^{2}\right)$, while 9 patients with 3 or 4 times (3/4) RTX infusions. At 6 months, $55.6 \%$ of the $1 / 2$ infusion group (10/18) and $44.4 \%$ of the $3 / 4$ infusion group (4/9) reached CR. At 6 months, mean PSL levels were $7.8 \mathrm{mg} /$ day in the $1 / 2$ infusion group and $6.6 \mathrm{mg} /$ day in the $3 / 4$ infusion group. At 18 months, $88.9 \%$ of the $1 / 2$ infusion group $(16 / 18)$ and $77.8 \%$ of the $3 / 4$ infusion group (7/9) were survived. $0 \%$ of the $1 / 2$ infusion group (0/18) and $33.3 \%$ of the $3 / 4$ infusion group (3/9) were relapsed. Severe adverse effects occurred in $38.9 \%$ of the $1 / 2$ infusion group $(7 / 18)$ and in $22.2 \%$ of the $3 / 4$ infusion group (2/9).

Conclusion: Our retrospective analysis indicated that cumulative $\mathrm{CR}$ rates and PSL tapering did not significantly differ between low-dose versus high-dose RTX as remission induction therapy in Japanese AAV patients, mostly elderly MPA patients, although there was no significant difference in severe adverse effects such as opportunistic infections between them. Disclosure of Interests: None declared DOI: 10.1136/annrheumdis-2019-eular.4450

\section{AB0591 POSITIVE PREDICTIVE VALUE OF THE GIANT CELL ARTERITIS DIAGNOSIS IN THE DANISH NATIONAL PATIENT REGISTRY: A VALIDATION STUDY}

Peter Hiort ${ }^{1}$, Philip Therkildsen ${ }^{1}$, Berit Dalsgaard Nielsen ${ }^{1}$, Ib Hansen $^{1}$, Annette de Thurah ${ }^{2}$, Ellen-Margrethe Hauge ${ }^{1} .{ }^{1}$ Aarhus University Hospital, Rheumatology, Aarhus, Denmark, ${ }^{2}$ Aarhus University Hospital, Aarhus, Denmark

Background: Giant cell arteritis (GCA) is the most frequent systemic vasculitis[1]. The diagnosis is clinical and based on symptoms, histopathology, biochemistry and imaging. In Denmark, diagnostic codes for all inand out-patient hospital diagnoses are registered in the Danish National Patient Registry (DNPR) [2]. Since GCA can be difficult to diagnose and treatment is initiated on suspicion, we hypothesized that the overall positive predictive value (PPV) of the GCA diagnosis code in the DNPR is low. High data quality is important for future epidemiological research in GCA.

Objectives: To establish PPV of the diagnostic code of GCA in the DNPR. Furthermore, to identify characteristics associated with a high PPV of the diagnostic code.

Methods: 293 patients aged $\geq 50$ years with a first-time register-based GCA diagnosis were included from the DNPR in the period January 2012-January 2018. Patients were sampled based on the ICD-10 codes (M31.5 and M31.6) from two regional hospitals and one university hospital in the Central Region of Denmark. As gold standard we used the medical records (including biochemistry, histopathology and imaging results) and categorized each patient as true GCA or non-GCA. Based on the data from the prescription database, patients were divided into four categories depending on the number of prednisolone prescriptions they received. Two independent investigators (PH and PT) reviewed the medical records. In case of disagreement the final diagnosis was reached by consensus or by expert opinion (ITH). To test how the PPV varied, 